\title{
IS THE ABILITY TO PERFORM TRANSURETHRAL RESECTION OF THE PROSTATE INFLUENCED BY THE SURGEON'S PREVIOUS EXPERIENCE?
}

\author{
José Cury, Rafael Ferreira Coelho, Homero Bruschini, Miguel Srougi \\ doi: $10.1590 / \mathbf{S 1 8 0 7 - 5 9 3 2 2 0 0 8 0 0 0 3 0 0 0 0 5}$
}

Cury J, Coelho RF, Bruschini H, Srougi M. Is the ability to perform transurethral resection of the prostate influenced by the surgeon's previous experience? Clinics. 2008;63:315-20.

PURPOSE: To evaluate the influence of the urologist's experience on the surgical results and complications of transurethral resection of the prostate (TURP).

PATIENTS AND METHODS: Sixty-seven patients undergoing transurethral resection of the prostate without the use of a video camera were randomly allocated into three groups according to the urologist's experience: a urologist having done 25 transurethral resections of the prostate (Group I - 24 patients); a urologist having done 50 transurethral resections of the prostate (Group II - 24 patients); a senior urologist with vast transurethral resection of the prostate experience (Group III - 19 patients). The following were recorded: the weight of resected tissue, the duration of the resection procedure, the volume of irrigation used, the amount of irrigation absorbed and the hemoglobin and sodium levels in the serum during the procedure.

RESULTS: There were no differences between the groups in the amount of irrigation fluid used per operation, the amount of irrigation fluid absorbed or hematocrit and hemoglobin variation during the procedure. The weight of resected tissue per minute was approximately four times higher in group III than in groups I and II. The mean absorbed irrigation fluid was similar between the groups, with no statistical difference between them $(\mathrm{p}=0.24)$. Four patients $(6 \%)$ presented with TUR syndrome, without a significant difference between the groups.

CONCLUSION: The senior urologist was capable of resecting four times more tissue per time unit than the more inexperienced surgeons. Therefore, a surgeon's experience may be important to reduce the risk of secondary TURP due to recurring adenomas or adenomas that were incompletely resected. However, the incidence of complications was the same between the three groups.

KEYWORDS: Prostatic hypertrophy. Transurethral resection of the prostate. TUR syndrome. Irrigation fluid. Morbidity. Hyponatremia.

\section{INTRODUCTION}

Despite the introduction of alternative techniques and pharmacological agents, transurethral resection of the prostate (TURP) remains a treatment of choice for benign prostatic obstruction, especially in Third World countries. ${ }^{1-3}$ Combined pharmacological therapy (alpha-adrenergic and 5-alpha-redutase inhibitor) faces two principal problems in developing countries: cost and patient compliance. ${ }^{1}$

Department of Urology, Hospital das Clínicas da Faculdade de Medicina da Universidade de São Paulo - São Paulo/SP, Brazil. coelhouro@yahoo.com.br

Received for publication on January 12, 2008

Accepted for publication on February 18, 2008
Combined therapy costs just over US $\$ 1.000$ per year, and a 55-year-old man can be expected to pay US $\$ 20.000$ for a lifetime supply of these drugs. Furthermore, in developing countries, once the patient feels better, he generally stops using the therapy and does not return to see his doctor., ${ }^{1,4}$ TURP costs under US $\$ 1.000$ and requires minimal followup. Therefore, evaluation of TURP technical improvements, surgical training, and surgical complications still has major importance in our developing country.

Since the introduction of TURP by McCarthy in 1926, the type of irrigating fluid that is used during the procedure and the method used to monitor its absorption have been subjects of wide-ranging debate. ${ }^{5,6}$ It is accepted that the irrigating fluid may enter the systemic circulation through 
the prostatic plexus of veins or via the periprostatic and perivesical space due to perforations of the prostatic capsule. ${ }^{6}$ Side-effects of irrigating fluid absorption can be deleterious; one of the more serious and potentially fatal side-effects is TUR syndrome. Estimates of the incidence of TUR syndrome range from 0 to $10 \%$. This syndrome is currently poorly defined, and many mild cases may be falsely attributed to old age, anesthetic complications, or excessive blood loss. ${ }^{5,7-10}$ The volume of absorbed irrigation fluid can be difficult to estimate; however, it tends to be greater in extended and bloody operations. ${ }^{6,11}$ Therefore, it is often claimed that inexperienced urologists and training residents more frequently induce irrigating fluid absorption and TUR syndrome than experienced urologists, who are capable of resecting more tissue per time unit. This hypothesis is controversial. ${ }^{4,5}$

In the present study, we evaluate the influence of the level of experience of a urologist on the surgical results and complications of classic TURP without the use of a video camera. We analyze the incidence of irrigating fluid absorption, resection time, amount of resected tissue and incidence of hyponatremia and TUR syndrome among three groups of urologists with different levels of experience with TURP. We used ethanol as a marker substance in the irrigating fluid. We performed a simple breath analysis to detect expired ethanol, which allows for early detection of irrigating fluid absorption, as described in previous studies. ${ }^{4,5}$

\section{PATIENTS AND METHODS}

Sixty-seven patients undergoing TURP in our university hospital were recruited to a prospective study and randomly allocated into one of three groups with varying urologist experience: a urologist in training having done 25 TURPs (Group I - 24 patients); a urologist after completing the residency program having done 50 TURPs (Group II - 24 patients); a senior urologist with vast TURP experience (Group III - 19 patients). All patients gave fully informed consent. There were no differences between the groups in mean age $(\mathrm{p}=0,49)$ or mean prostatic weight $(\mathrm{p}=0,68)$ in sonography (Table 1).

The patients were given spinal anesthesia. The operative technique was the classic McCarthy technique with median lobe and lateral lobe resection until open vision of the bladder was obtained. All of the procedures were done using a 24Fr resectoscope with concomitant suprapubic drainage (continuous flow resection). A video camera was not used for the resection. Sorbitol was used as the irrigating fluid (sorbitol 2,7 g/100 ml). Ethanol (99.5\%) was added to the irrigating fluid at a final concentration of $1 \%$. The height of the irrigating fluid was uniformly up to $60 \mathrm{~cm}$.

In all patients, the weight of resected tissue, duration of TURP, the volume of irrigant used and evidence of prostatic capsule perforation were recorded. The amount of irrigant that was absorbed was measured by breath ethanol levels on an alcolmeter. The ethanol level in expired air was determined at the start of the operation and once every ten minutes during the operation. Blood samples were taken once every ten minutes to measure the hemoglobin, hematocrit, and sodium levels. The irrigant absorption level was determined by a linear equation described by Hahn ${ }^{9}$ [Absorption $=(2,14 \times 3,43$. EB-ethanol $) X \Delta$ EB ethanol + $(44+806$ X EB-ethanol)].

TUR syndrome was defined as a sodium level after TURP of $\leq 125 \mathrm{mmol} / \mathrm{L}$ with two or more symptoms or signs of TUR syndrome: nausea, vomiting, bradycardia,

Table 1- Comparison of urologists with different levels of TURP experience

\begin{tabular}{|c|c|c|c|c|}
\hline & $\begin{array}{c}\text { - Group I - } \\
\text { Median/Mean (range) } \pm \\
\text { standard deviation }\end{array}$ & $\begin{array}{c}\text { - Group II - } \\
\text { Median/Mean (range) } \pm \\
\text { standard deviation }\end{array}$ & $\begin{array}{c}\text { - Group III - } \\
\text { Median/Mean (range) } \pm \\
\text { standard deviation }\end{array}$ & Significance \\
\hline Number of patients & 24 & 24 & 19 & \\
\hline Age - years & $\begin{array}{c}63 / 63 \pm 6.5 \\
(48-78)\end{array}$ & $\begin{array}{c}66 / 65.2 \pm 6.75 \\
(50-74)\end{array}$ & $\begin{array}{l}65 / 64.3 \pm 6 \\
(54-76)\end{array}$ & 0.49 \\
\hline USG prostatic weight - $\mathrm{g}$ & $\begin{array}{c}46.5 / 45 \pm 20.4 \\
(13-96)\end{array}$ & $\begin{array}{c}41.5 / 46.3 \pm 41.5 \\
(23-151)\end{array}$ & $\begin{array}{c}49 / 51 \pm 22 \\
(18-90)\end{array}$ & 0.68 \\
\hline Resection Time - minutes & $\begin{array}{l}45 / 45.8 \pm 11 \\
(30-65)\end{array}$ & $\begin{array}{c}50 / 49.8 \pm 12.9 \\
(30-80)\end{array}$ & $\begin{array}{l}30 / 30.5 \pm 10 \\
\quad(14-45)\end{array}$ & $\begin{array}{c}<0.01 \\
(\mathrm{I}=\mathrm{II}>\mathrm{III})\end{array}$ \\
\hline Resected Tissue - g & $\begin{array}{l}9 / 12.4 \pm 9 \\
(2-30)\end{array}$ & $\begin{array}{c}12.5 / 13.8 \pm 7.1 \\
(2-36)\end{array}$ & $\begin{array}{c}25 / 33.3 \pm 24.6 \\
(5-85)\end{array}$ & $\begin{array}{c}<0.01 \\
(\mathrm{I}=\mathrm{II}<\mathrm{III})\end{array}$ \\
\hline $\begin{array}{l}\text { Resected Tissue/op time } \\
\text { - g/min }\end{array}$ & $\begin{array}{l}0.26 / 0.26 \pm 0.15 \\
(0.04-0.53)\end{array}$ & $\begin{array}{l}0.26 / 0.27 \pm 0.10 \\
(0.04-0.56)\end{array}$ & $\begin{array}{l}0.83 / 1.07 \pm 0.63 \\
(0.11-2.25)\end{array}$ & $\begin{array}{c}<0.01 \\
(\mathrm{I}=\mathrm{II}<\mathrm{III})\end{array}$ \\
\hline Irrigating Fluid Used (L) & $\begin{array}{l}10 / 11.5 \pm 5.4 \\
(4.5-26)\end{array}$ & $\begin{array}{l}11 / 11.7 \pm 4 \\
(6-21)\end{array}$ & $\begin{array}{l}12.5 / 13.6 \pm 5.8 \\
\quad(7.5-26)\end{array}$ & 0.34 \\
\hline
\end{tabular}


hypotension, hypertension, chest pain, mental confusion, anxiety, paresthesia, and visual disturbances. ${ }^{4,8}$

We used parametric tests for statistical analysis. Scheffé's multiple comparison analysis was used for comparisons between the three groups. When only two groups were compared, we used the student's t-test. We used the nonparametric Kruskal-Wallis Test for analysis of the absorbed volume of irrigating fluid. Qualitative variables were assessed by the chi-squared test. Statistical significance in this study was set as $\mathrm{p} \leq 0,05$.

\section{RESULTS}

There were no differences between the groups with regard to the amount of irrigation fluid used per operation, the amount of absorbed fluid irrigant (Table 1), or hematocrit and hemoglobin variation during the procedure (Figure 1A $1 \mathrm{~B})$. The operating time was significantly longer in groups I and II compared to group III and the weight of resected

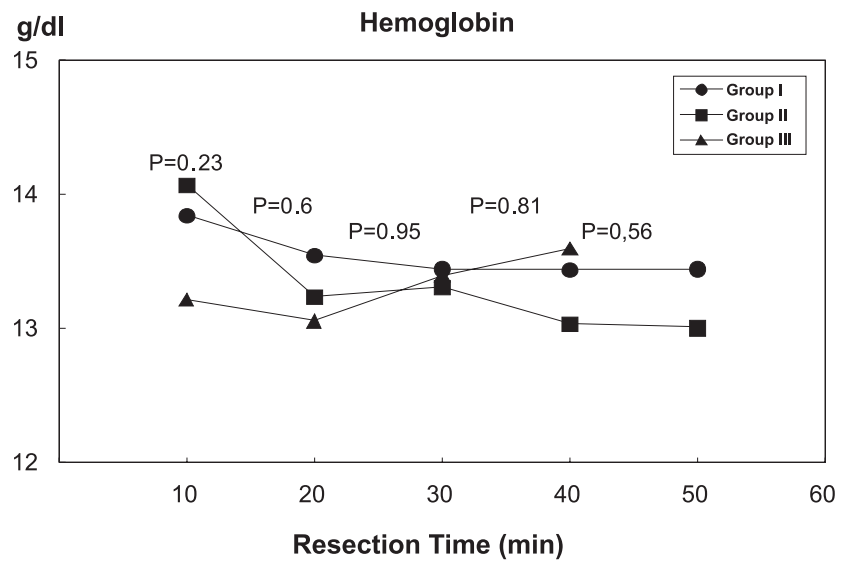

Figure 1A - Mean hemoglobin levels during TURP.

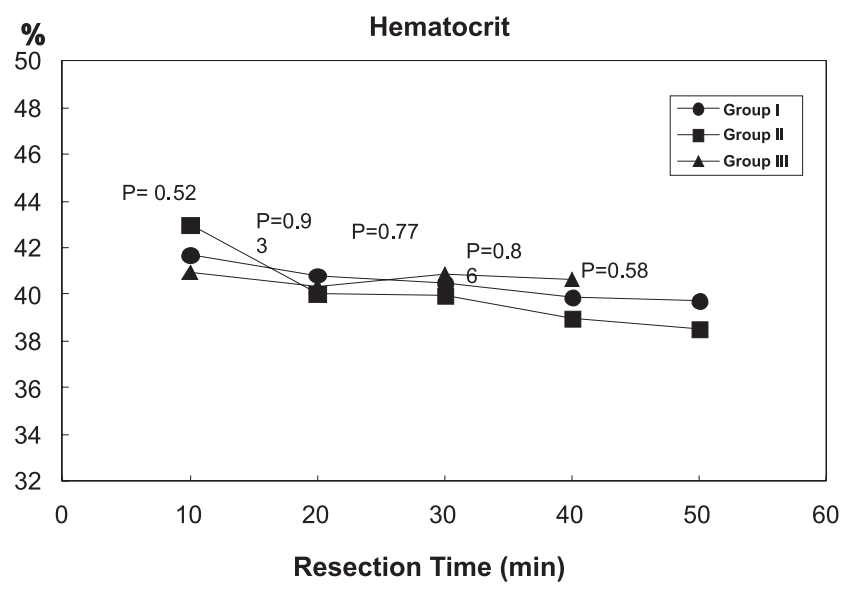

Figure 1B - Mean hematocrit levels during TURP. tissue was significantly greater in group III relative to the other groups. The weight of resected tissue per minute was approximately four times higher in group III than in groups I and II. (Table 1).

The presence of ethanol in expired air, which signals the absorption of irrigating fluid, was detected in $8 / 24$ (33\%) patients in group I, 9/24 (37\%) patients in group II, and $11 / 17(58 \%)$ patients in group III. The differences in the $\%$ of patients that absorbed irrigating fluid among the three groups did not reach statistical significance $(\mathrm{p}=0,233)$. Figure 2 shows the volumes of absorbed irrigating fluid in excess of and less than $1000 \mathrm{ml}$ in the three groups. The mean/median volume \pm standard deviation (range) of absorbed irrigating fluid was 1099/1131 $\pm 540(310-1965)$ $\mathrm{ml}$ in group I, 1063/1016 $\pm 553(418-2160) \mathrm{ml}$ in group II, and 743/504 $\pm 510(234-1848) \mathrm{ml}$ in group III. There was no statistically significant difference between these values $(\mathrm{p}=0,2457)$.

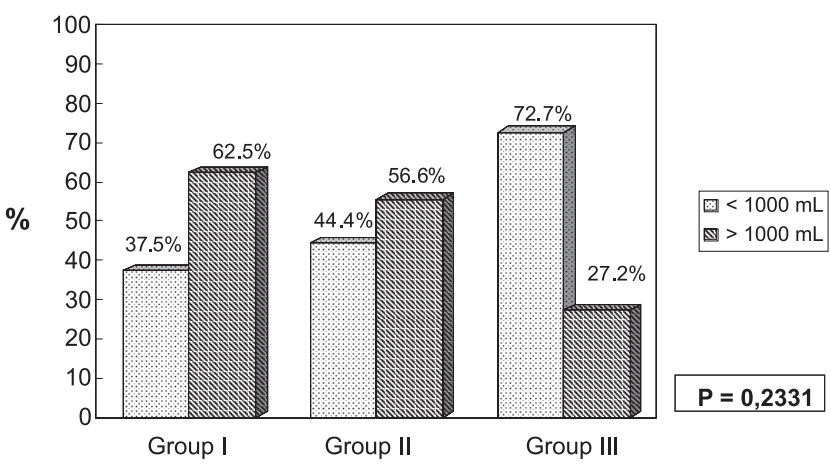

Figure 2 - Irrigating fluid absorption in the three groups.

Figure 3 shows the mean serum sodium variation during TURP in the three groups. The mean serum sodium level was normal in group III during all TURP periods. The mean serum sodium levels after 10, 20, and 30 minutes of TURP were significantly lower in groups I and II than in group III. Importantly, the mean serum sodium levels in groups I and II were higher than $129 \mathrm{mEq} / \mathrm{l}$ during all TURP periods that were studied.

Four patients $(6 \%)$ developed TUR syndrome during or after the TURP procedure, without a significant difference in the incidence between the three groups. Two patients in group I (8,3\%) presented with TUR syndrome; they absorbed $1965 \mathrm{ml}$ and $1637 \mathrm{ml}$ of irrigating fluid, respectively. The lowest serum sodium level in the first patient, $108 \mathrm{mEq} / \mathrm{l}$, was detected 40 minutes after the onset of TURP. He exhibited nausea, paresthesia, and mental confusion. The lowest serum sodium level in the second patient, $117 \mathrm{mEq} / \mathrm{l}$, was detected 30 minutes after the onset of resection. $\mathrm{He}$ had nausea and mental confusion. In group II, one patient 


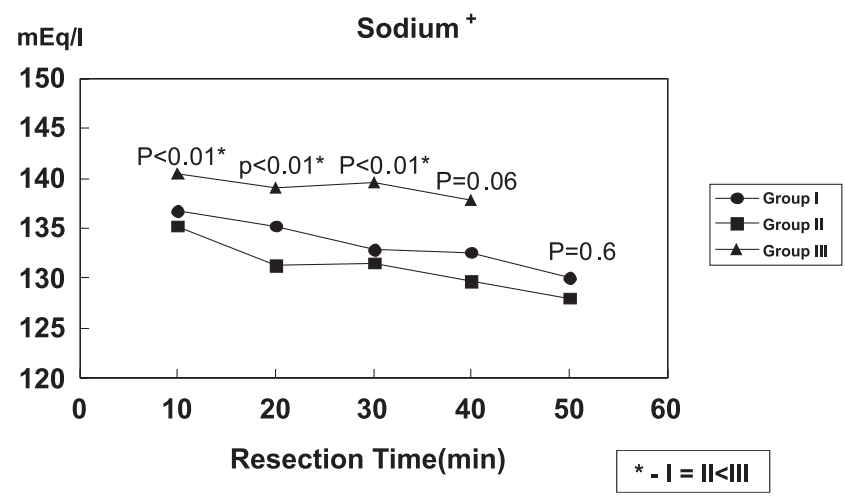

Figure 3 - Mean serum sodium levels during TURP in the three groups.

$(4,1 \%)$ absorbed $1482 \mathrm{ml}$ of irrigating fluid and presented with TUR symptoms and a serum sodium level of 117 $\mathrm{mEq} / \mathrm{l}$ during the first 20 minutes of TURP. Finally, in group III, one patient $(5,2 \%)$ absorbed $1848 \mathrm{ml}$ of irrigating fluid and became oliguric 18 hours after the procedure. In this patient, the serum creatinine level reached $12 \mathrm{mg} / \mathrm{dl}$, and the lowest detected serum sodium level was $107 \mathrm{mEq} / \mathrm{L}$. His renal function completely recovered after medical treatment without the need for dialysis. The other three patients that suffered from TUR symptoms, as described above, also had good clinical evolutions and serum sodium level normalization after medical treatment.

\section{DISCUSSION}

Despite the development of effective medical therapy for TURP and the decline in its frequency in many countries over the past decade, it is still one of the most common interventions in elderly men, especially in developing countries. ${ }^{12-15}$ Today, technological improvements, such as microprocessor-controlled units, better armamentarium, and facilities for medical training have helped to reduce perioperative complications, such as transfusion rate, clot retention, and TUR syndrome. ${ }^{1}$ The introduction of video camera-assisted TURP and the development of virtual reality training systems for TURP have enhanced training on this procedure, provided more physical comfort to the surgeon, improved the technical skills of surgeons and reduced complications rates and hospital stays. ${ }^{16,17}$ The need for complete resection of a prostate adenoma was recently questioned since partial resections can produce short term functional results comparable to those of standard TURP with a short surgical time and minor complications. ${ }^{18}$ Finally, the introduction of bipolar resection devices for TURP has allowed for coagulation of tissue during resection, using normal saline as the irrigant fluid. This technique has reduced the potential for TUR syndrome and allowed for earlier removal of the urinary catheter and discharge from the hospital, while simultaneously decreasing complications, as indicated by some recent studies. ${ }^{19-21}$ Therefore, in this environment, the influence of a surgeon's experience on the results and complications of TURP is questionable.

In developing countries, however, the virtual reality training system, bipolar resection devices and video camera-assisted TURP are not always available. Surgeons in developing countries hone their surgical skills in the operating room. Therefore, learning and practice of the standard TURP procedure, without video camera assistance, is of great importance. Here, we compared the results of standard TURP procedures performed by urologists with three different levels of experience in our residency training hospital. The senior urologist (group III) resected significantly more material per patient in less surgical time than the inexperienced urologist (Group I and II). He was capable of resecting four times more tissue per time unit than the inexperienced surgeons. We suggest that this ability is of great importance, as it indicates that resections performed by experienced urologists should have a lower frequency of re-TURP due to recurrent adenomas or adenomas that were incompletely resected. Previous reports have shown that the risk for a secondary TURP was approximately $50 \%$ higher after primary TURP as compared to open prostatectomy, which involves more complete resection of the adenoma. The cumulative probability of a second prostatectomy ranges from 6,6 to $15 \%$ over 6 to 8 years in long-term series; this incidence may be higher when the TURP is performed by an inexperienced surgeon. ${ }^{13}$ In developing countries, where the costs of medical therapy may be prohibitive, patients tend to undergo surgical treatment precociously, and the need for a secondary TURP in a long-term follow-up is emphasized. ${ }^{2}$ This second procedure burdens the health system and increases patient morbidity.

The TUR syndrome is a potential complication of TURP in countries where bipolar saline TURP is not available. The incidence of TUR syndrome in our study was $6 \%$. Interestingly, the volume of irrigating fluid used, the mean irrigating fluid absorbed, and the proportion of patients that absorbed more than $1000 \mathrm{ml}$ of irrigating fluid were not statistically different among patients attended to by experienced and inexperienced urologists. Also, the mean hematocrit and hemoglobin levels during TURP were statistically similar between the groups. Mean serum sodium levels during TURP were lower in the patients attended to by the inexperienced urologist than in those attended to by the experienced urologist. However, the lower mean sodium levels during TURP in these groups (I and II) were higher than $129 \mathrm{mEq} / \mathrm{L}$ (mild hyponatremia), and the incidences of TUR syndrome were similar among the three groups. 
Therefore, our data do not support the hypothesis that experienced urologists have fewer problems with absorption of irrigating fluid, hyponatremia, and bleeding than inexperienced urologists. A probable explanation for this is that an experienced urologist operates quickly and perhaps more aggressively and radically. This might aggravate the risk of absorption of more irrigating fluid since the capsule is reached more quickly and may be perforated and also because the great veins are opened earlier in the operation. The inexperienced urologist is perhaps more careful, preferring to leave some tissue close to the capsule rather than risk a perforation and open veins, which reduces the risk of fluid absorption. The price for this conservative behaviour is a higher risk of re-TURP due to recurring adenomas, as we emphasized above. Importantly, other studies have also shown that the experience of the surgeon is not significantly predictive of irrigation fluid absorption. ${ }^{4,5}$

In conclusion, the senior urologist was capable of resecting four times more tissue per time unit than the inexperienced surgeons. The surgeon's experience may be important for reducing the risk of secondary TURP due to recurring adenomas or adenomas that were incompletely resected. However, the incidence of complications was the same among the three groups. We suggest that this is the case because the senior urologist operates more quickly and is likely more radical in the resection and therefore, he reaches the capsule and opens the great veins earlier in the operation relative to the more inexperienced urologists.

\section{REFERENCES}

1. Rassweiler J, Teber D, Kuntz R, Hofmann R. Complications of the Transurethral Reseciton of the prostate (TURP) - Incidence, Management and Prevention. Eur Urol. 2006;50:969-79.

2. Sharma DP. The management of benign prostatic obstruction: a voice from the Third World. BJU Int. 2006;97:671-2.

3. El Hayek OR, Alfer JR. W, Reggio E, Pompeu ACL, Arap S, Srougi M. Percutaneous prostate cryoablation as treatment for high-risk prostate cancer. Clinics. 2007;62:109-12.

4. Ogbonna BC, Okeahialam BN, RamyilVM. Alpha-receptor blockade for benign prostatic hyperplasia: uses and problems in a developing country.Br J Urol 1997;79:32-5.

5. Collins JW, McDermott S, Bradbrook RA, Keeley Jr FX, Timoney G. A comparison of the effect of $1.5 \%$ glycine and $5 \%$ glucose irrigants on plasma serum physiology and the incidence of transurethral resection syndrome during prostate resection. BJU International. 2005;96:368-72

6. Hjertberg H, Jorfeldt L, Schelin S. Use of ethanol as marker substance to increase patient safety during TURP. Urology 1991;38:423-8.

7. Harrison III RH, Boren JS, Robinson JR. Dilutional hyponatremic shock: another concept of the transurethral prostatic resection reaction. J. Urol. 1956;75:96-110
8. Weis N, Jorgensen PE, Bruun E. "TUR syndrome" after transurethral resection of the prostate using suprapubic trocar. Int. Urol. Nephrol 1987;19:165-69.

9. Mebust WK, Holtgrewe HL, Cockett ATK, Peters PC, and writing committee: Transurethral prostatectomy: immediate and postoperative complications. A cooperative study of 13 participating institutions evaluating 3.885 patients. J. Urol. 1989;141:243-7.

10. Hahn, R.G. - Early detection of the TUR syndrome by marking the irrigating fluid with 1\% ethanol. Acta Anaesthes Scand 1989;33:146-51.

11. Hahn RG, Ekengren JC. Patterns of irrigating fluid absorption during transurethral resection of the prostate as indicated by ethanol. J. Urol. 1993;149:502-6.

12. Berges RR, Pientka L. Management of BPH Syndrome in Germany: Who is treated and how? Eur Urol 1996;36 (Suppl 3):21-7.

13. Madersbacher S, Marberg M. Is transurethral resection of the prostate still justified? BJU Int 1999;83:227-37.

14. Madersbacher S, Lackner J, Brossner C, Röhlich M, Stancik I, Willinger M, et al. Prostate Study Group of the Austrian Society of Urology. Reoperation, myocardial infarction and mortality after transurethral and open prostatectomy: a nation-wide, long-term analysis of 23,123 cases. Eur Urol. 2005;47:499-504. 
15. De la Rosette JJ, Alivizatos J, Madersbacher S Perachino M, Thomas $\mathrm{D}$, Desgrandchamps $\mathrm{F}$, et al. EUA guidelines on benign prostatic hyperplasia (BPH). Eur Urol 2001;40:256-63

16. Nouira Y, Kbaier I, Attyaoui F, Horchani A. How did the endoscopic video camera change our practice in transurethral resection of the prostate? A retrospective study of 200 cases. J Endourol. 2002;16:763-5.

17. Kallstrom R, Hjertberg H, Kjolhede H, Svanvik J. Use of a virtual reality, real-time, simulation model for the training of urologists in transurethral resection of the prostate. Scand J Urol Nephrol. 2005; 39(4):313-20.

18. Agrawal MS, Aron M, Goel R. Hemiresection of the prostate: shortterm randomized comparison with standard transurethral resection. J Endourol. 2005;19:868-72.
19. Starkman JS, Santucci RA. Comparison of bipolar transurethral resection of the prostate with standard transurethral prostatectomy: shorter stay, earlier catheter removal and fewer complications. BJU Int. 2005;95:69-71.

20. Singh H, Desai MR, Shrivastav P, Vani K. Bipolar versus monopolar transurethral resection of prostate: randomized controlled study.J Endourol. 2005;19:333-8.

21. de Sio M, Autorino R, Quarto G, Damiano R, Perdona S, di Lorenzo G, et al. Gyrus bipolar versus standard monopolar transurethral resection of the prostate: a randomized prospective trial. Urology. 2006;67:69-72. 